\title{
Nitric oxide modulates ATP-evoked currents in mouse Leydig cells
}

\author{
J.L. de Deus, A.L.A. Dagostin and W.A. Varanda
}

Departamento de Fisiologia, Faculdade de Medicina de Ribeirão Preto, Universidade de São Paulo, Ribeirão Preto, SP, Brasil

\begin{abstract}
Testosterone synthesis within Leydig cells is a calcium-dependent process. Intracellular calcium levels are regulated by different processes including ATP-activated P2X purinergic receptors, T-type $\mathrm{Ca}^{2+}$ channels modulated by the luteinizing hormone, and intracellular calcium storages recruited by a calcium-induced calcium release mechanism. On the other hand, nitric oxide (NO) is reported to have an inhibitory role in testosterone production. Based on these observations, we investigated the interaction between the purinergic and nitrergic systems in Leydig cells of adult mice. For this purpose, we recorded ATP-evoked currents in isolated Leydig cells using the whole cell patch clamp technique after treatment with L-NAME (300 $\mu \mathrm{M}$ and $1 \mathrm{mM})$, L-arginine $(10,100,300$, and $500 \mu \mathrm{M}), \mathrm{ODQ}(300 \mu \mathrm{M})$, and 8-Br-cGMP $(100 \mu \mathrm{M})$. Our results show that NO produced by Leydig cells in basal conditions is insufficient to change the ATP-evoked currents and that extra NO provided by adding $300 \mu \mathrm{M}$ L-arginine positively modulates the current through a mechanism involving the NO/cGMP signaling pathway. Thus, we report an interaction between the nitrergic and purinergic systems in Leydig cells and suggest that $\mathrm{Ca}^{2+}$ entry via the purinergic receptors can be regulated by NO.
\end{abstract}

Key words: Leydig cells; ATP; Purinergic receptor; Calcium; Nitric oxide; Whole cell patch clamp

\section{Introduction}

The involvement of $\mathrm{Ca}^{2+}$ in Leydig cell's testosterone synthesis was suggested by Janszen et al. (1) by showing that the production of the hormone induced by the luteinizing hormone was dependent on the presence of $\mathrm{Ca}^{2+}$ in the extracellular solution. Other studies investigating the role of calcium ions in the steroidogenic process showed that application of ATP onto the cell increased the intracellular $\mathrm{Ca}^{2+}$ concentration (2) and the production of the steroid via activation of P2 receptors in Leydig cells (3). More recently our group demonstrated that $\mathrm{P} 2 \mathrm{X}$ receptors, which have pharmacological and electrophysiological properties similar to $\mathrm{P} 2 \mathrm{X} 2$ receptors, are present in the plasma membrane of mice Leydig cells (4). Moreover, Antonio et al. $(5,6)$ showed that $\mathrm{P} 2 \mathrm{X} 2, \mathrm{P} 2 \mathrm{X} 4, \mathrm{P} 2 \mathrm{X} 6, \mathrm{P} 2 \mathrm{X} 7$ subunits are present in Leydig cells, possibly arranged as heterotrimers to form $\mathrm{P} 2 \mathrm{X} 2 / 4 / 6$ receptors.

Therefore, the increase in intracellular calcium concentration $\left(\left[\mathrm{Ca}^{2+}\right]_{i}\right)$ due to $\mathrm{P} 2 \mathrm{X}$ receptor activation is one of the processes that can enhance steroidogenesis in Leydig cells. On the other hand, nitric oxide (NO) has also been taken as a global modulator of this process. However, its role in testosterone production is not completely understood. Several studies have shown an inverse relationship between $\mathrm{NO}$ and testosterone production/ secretion: inhibition of $\mathrm{NO}$ production induces an increase in the plasma levels of the hormone (7-11). In addition, Valenti et al. (12) showed a biphasic relationship in which higher concentrations of NO donors (S-nitroso-N-ncetyl-D, L-penicillamine, diethylamine NONOate, and diethylenetriamine NONOate) decreased testosterone production while lower concentrations of these compounds increased hormone levels. The formation of NO is catalyzed by three different enzymes, and two of them, the endothelial and the neuronal nitric oxide synthases (NOS) rely on an increased intracellular $\mathrm{Ca}^{2+}$ concentration to be activated (13) and are present in Leydig cells $(14,15)$.

Different cell types have nitrergic and purinergic signaling pathways that interact with each other, determining the final physiological response. In the cochlear hair cells, ATP induces the production of $\mathrm{NO}$ by activation of $\mathrm{P} 2$ purinergic receptors (16). In rat hypothalamus, P2X2 receptors and neuronal NOS co-localize in the supraoptic nucleus and rostroventrolateral medulla neurons (17). In the thick ascending limb of the nephron, there is a decrease in NO production when either suramin or L-N-nitro-arginine methyl ester (L-NAME) are applied before application of extracellular ATP (18). In carotid body neurons, extracellular ATP increases intracellular $\mathrm{Ca}^{2+}$, triggering $\mathrm{NO}$ production (19).

Correspondence: J.L. de Deus: <junia_lara@usp.br> 
The above examples show that the purinergic and nitrergic systems act on several physiological processes, even though ATP and NO have different molecular identities.

Based on evidence showing the interaction between these systems in different cells, the aim of the present work was to study the relationship between the actions of $\mathrm{NO}$ and ATP-evoked purinergic currents in mice Leydig cells with the whole cell patch clamp technique.

\section{Material and Methods}

\section{Cells}

The protocols used in this study were conducted in accordance with the Ethical Principles on Animal Experimentation adopted by the National Council of Animal Experimentation Control (CONCEA) and approved by the Institutional Ethical Committee on Animal Experimentation of the Faculdade de Medicina de Ribeirão Preto, Universidade de São Paulo (\#018/2013).

Leydig cells were obtained from 42-day-old male Swiss mice. The animals were killed by cervical dislocation and the testes were quickly removed and freed from fat and the surrounding tunica albuginea. They were placed in Hank's solution containing: $140 \mathrm{mM} \mathrm{NaCl}, 4.6 \mathrm{mM} \mathrm{KCl}$, $1.6 \mathrm{mM} \mathrm{CaCl}_{2}, 1.13 \mathrm{mM} \mathrm{MgCl}_{2}, 10 \mathrm{mM}$ Hepes, $10 \mathrm{D}$-glucose, and $5 \mathrm{mM} \mathrm{NaHCO}_{3}$, with osmolality ranging from 290$300 \mathrm{mOsm} / \mathrm{kg}$ and $\mathrm{pH} 7.4$ adjusted with $\mathrm{NaOH}$. Leydig cells were collected by mechanical dispersion (aspiration/ suction with a 27-gauge needle and a syringe) of the testis with the same solution and plated on glass coverslips. For recordings, the coverslips were transferred to a perfusion chamber mounted on the stage of an inverted microscope (Axiovert $40 \mathrm{CFL}$, Carl Zeiss, Germany) no more than $4 \mathrm{~h}$ after isolation (4).

\section{Electrophysiological recordings}

The patch clamp technique in the whole cell voltage clamp configuration was used for measuring the evoked purinergic currents. Micropipettes were pulled from borosilicate glass capillaries (Sutter Instruments Co., USA) in a P-97 puller (Sutter Instruments Co.) and had resistance ranging from 3-4 $\mathrm{M} \Omega$ when backfilled with the internal solution containing $140 \mathrm{mM}$ potassium gluconate, $10 \mathrm{mM}$ $\mathrm{KCl}, 1 \mathrm{mM} \mathrm{MgCl}$, $10 \mathrm{mM}$ Hepes, $1 \mathrm{mM}$ EGTA, $0.75 \mathrm{mM}$ $\mathrm{CaCl}_{2}, 2 \mathrm{mM} \mathrm{Na-ATP}$, and $0.25 \mathrm{mM} \mathrm{Na}-\mathrm{GTP}$, with osmolality between 285 and $295 \mathrm{mOsm} / \mathrm{kg}$ and $\mathrm{pH} 7.3$ adjusted with $\mathrm{KOH}$. Ionic currents were measured with an Axopatch $200 \mathrm{~B}$ amplifier, filtered at $2 \mathrm{KHz}$ and digitized at $5 \mathrm{KHz}$ through a Digidata 1440A AD/DA converter (Molecular Devices, USA), controlled by the software PClamp 10. Cells with series resistance larger than $20 \mathrm{M} \Omega$ were discarded.

Drugs were diluted to the desired final concentration in the extracellular solution and applied to the cells via a rapid solution changer system (RSC - Bio-Logic Co.,
France). To construct the current versus voltage $(\mathrm{I} \times \mathrm{V})$ plots, voltage ramps from -100 to $+40 \mathrm{mV}$ (500 ms long) were applied $800 \mathrm{~ms}$ after the beginning of the ATP superfusion. This delay is necessary to get the current response at its peak and was extended for another $100 \mathrm{~ms}$ after the ramp was terminated. Thus, the ATP application lasted for $1400 \mathrm{~ms}$. This protocol was first applied with ATP only, 5 min after the whole cell configuration was achieved, and the subsequent ATP pulses were delivered in 5-min intervals. With L-arginine $(10,100,300$, and $500 \mu \mathrm{M})$, the protocol was repeated and the recordings were made $5 \mathrm{~min}$ after whole cell mode establishment and a final recording after a 15-min washout.

ATP-evoked currents triggered in cells treated with L-NAME $(300 \mu \mathrm{M}$ and $1 \mathrm{mM}), 8-B r-G M P c(100 \mu \mathrm{M})$ and ODQ $(300 \mu \mathrm{M})$ were recorded $5 \mathrm{~min}$ after the establishment of the whole cell configuration and after $10 \mathrm{~min}$ of treatment with each drug. ATP, L-arginine (L-NG monomethyl arginine), L-NAME, 8-Br-GMPc (8-bromoguanosine $3^{\prime}, 5^{\prime}$-cyclic monophosphate sodium) and ODQ $(1 \mathrm{H}-(1,2,4)$ oxadiazolo[4,3-A]-quinoxalin-1-one) were purchased from Sigma-Aldrich Co. (USA).

\section{Statistical analysis}

Data were analyzed by descriptive statistics and are reported as means $\pm S E$. The comparison between variables was performed using one-way ANOVA and Tukey's post-test, and the unpaired $t$-test with a significance level of $5 \%(P \leqslant 0.05)$. Data analysis was done with Prism version 5.0 (GraphPad Software, USA) and Origin Pro 6.0 (Origin Lab Corporation, USA). For comparison between different treatments, current amplitudes were measured at $-70 \mathrm{mV}$ and averaged.

\section{Results}

\section{Thorough washout and short ATP pulses prevented currents from strong desensitization}

Purinergic receptors desensitize after long exposure to the agonist. Since our essays required repetitive cell exposure to ATP, we carried out an experiment to demonstrate that desensitization was not significant under our experimental conditions. Figure $1 \mathrm{~A}$ shows superimposed IxV plots recorded during ATP applications separated by 5-min intervals. The responses are hardly distinguishable from one another. For comparison purposes, Figure 1B shows averaged values ( $n=7$ cells) of the current amplitudes measured at $-70 \mathrm{mV}$ : control: $-225.4 \pm 60.9,5 \mathrm{~min}$ : $-226.9 \pm 58.4,10 \mathrm{~min}:-215.4 \pm 83.0$, and $15 \mathrm{~min}:-198.9$ \pm 72.7 , pA; $P=0.3$. These results show that in our experimental conditions (ATP applied for $1400 \mathrm{~ms}+5 \mathrm{~min}$ washout), the evoked purinergic currents suffered no significant desensitization. Therefore, any observed changes in amplitude can be associated with the pharmacological manipulation performed in each case. 
A

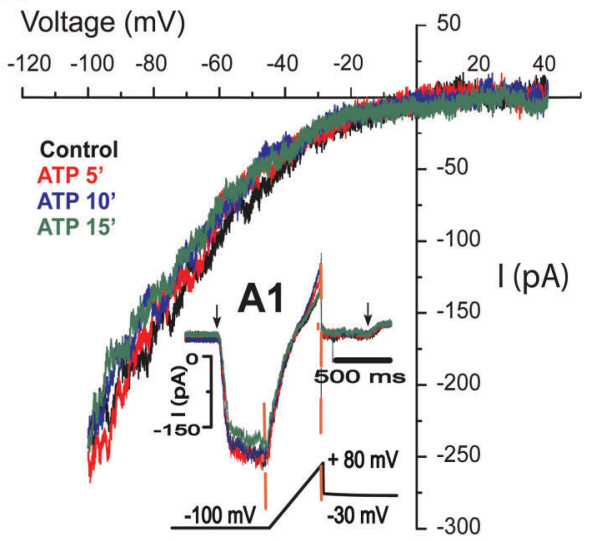

B

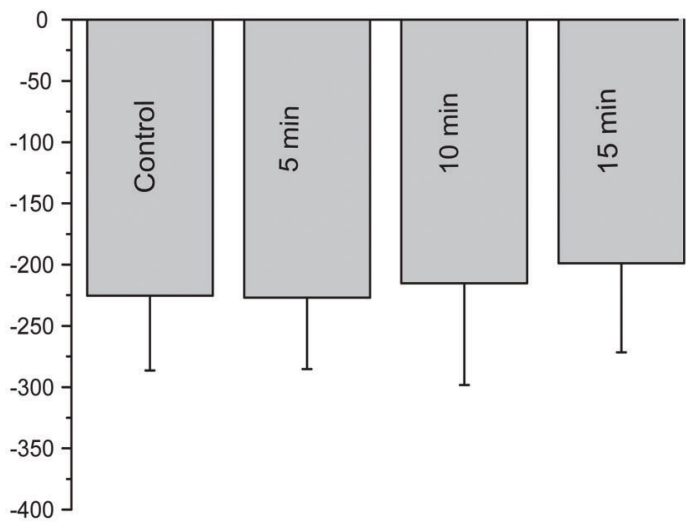

Figure 1. ATP-evoked currents did not show significant desensitization under the present experimental conditions. $A$, Current-voltage $(\mathrm{I} \times \mathrm{V})$ plot obtained in response to $100 \mu \mathrm{M}$ ATP application in control condition (first application - black) and after 5 (red), 10 (blue), and $15 \mathrm{~min}$ (green). The inset shows the voltage protocol used as well as the total current response. Note that application of ATP (arrows), with the cell held at $-100 \mathrm{mV}$, induces a fast activating inward current. At the peak of the current response a voltage ramp going from -100 to $+80 \mathrm{mV}$, with $500 \mathrm{~ms}$ duration, was applied and this corresponds to the IxV plot shown. The plot displays the response up to $+40 \mathrm{mV}$ only, because other currents start to activate beyond this point. This same procedure was used in all other experiments. $B$, Bar graph showing the means \pm SE of currents measured at $-70 \mathrm{mV}(\mathrm{n}=7$ cells). The cells were continuously superfused with control solution between ATP pulses. $P \geqslant 0.05$, ANOVA and Tukey post-test.

\section{Basal NO production did not affect the ATP-evoked current}

Since NOS isoforms are present in Leydig cells, we assumed that L-NAME, a non-selective NOS inhibitor, would block NO synthesis and, consequently, a possible basal nitrergic inhibition of purinergic currents. However, L-NAME did not impair the ATP-evoked currents after 5 $(-722.5 \pm 331.5 \mathrm{pA}), 10(-688.9 \pm 302.8 \mathrm{pA})$, and $15 \mathrm{~min}$ $(-637.0 \pm 273.5 \mathrm{pA})$ compared to control $(-673.2 \pm 349.4$ $\mathrm{pA} ; \mathrm{P}=0.95 ; \mathrm{n}=5$ cells (Figure $2 \mathrm{~A}$ and $\mathrm{B}$ ). Figure $2 \mathrm{C}$ and $\mathrm{D}$ reinforce this aspect, since the ATP-evoked currents measured after a 10 min incubation with $300 \mu \mathrm{M}$ L-NAME are not significantly different from values acquired after washing out the drug for another $15 \mathrm{~min}$ (L-NAME: -756.7 \pm 416.8 pA; wash: $-687.6 \pm 398.0 \mathrm{pA} ; \mathrm{P}=0.4 ; \mathrm{n}=5)$. Since we observed no significant difference, we may suggest that basal NO did not modulate the ATP-evoked current.

\section{Nitrergic modulation of ATP-evoked currents induced by L-arginine}

Since basal NO production did not affect the ATPevoked current amplitudes, we gradually increased the bath concentration of L-arginine to increase NO production and observe its effect on the purinergic currents (Figure 3A-D with 10, 100, 300, and $500 \mu \mathrm{M}$ L-arginine). As can be seen, of the different concentrations of L-arginine used, only $300 \mu \mathrm{M}$ significantly altered the purinergic currents (Figure 3C'). The ATP-evoked current amplitudes increased after treatment with L-arginine in 5,10 , and $15 \mathrm{~min}$, and this effect was reversed upon L-arginine washout $(P \leqslant 0.05)$

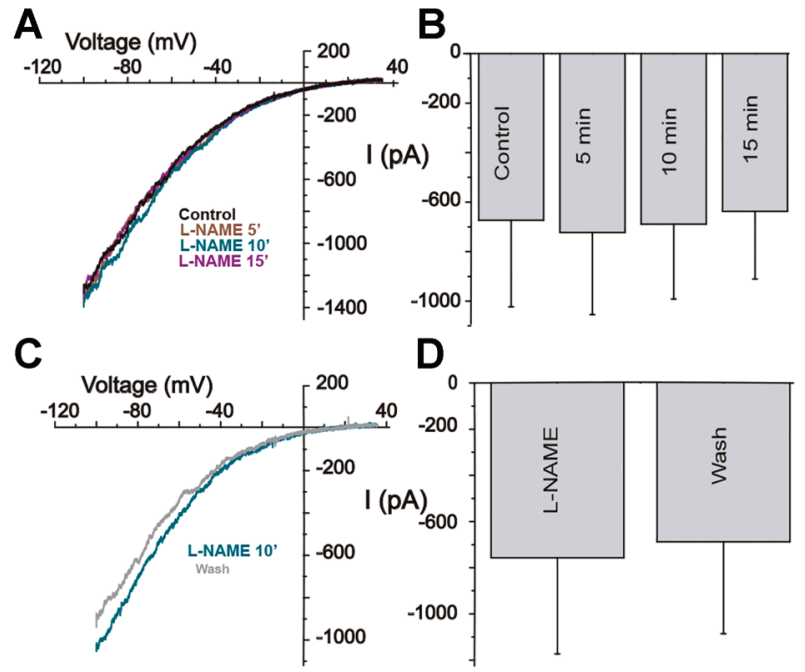

Figure 2. L-NAME did not impair purinergic currents. A, ATPelicited currents I $\times$ V plot after treatment with $300 \mu \mathrm{M}$ L-NAME for 5 (brown), 10 (light green) and 15 (purple) min. C, ATP-elicited currents IXV plot after treatment with $300 \mu \mathrm{M}$ L-NAME for $10 \mathrm{~min}$ (light green) and after 15 min' wash (gray). $B$ ( $\mathrm{n}=5$ cells) and $D$ $(n=5$ cells), bar graphs showing the means \pm SE of the currents measured at $-70 \mathrm{mV}$. No significant changes were observed in the amplitude of the currents. Panel $B: P \geqslant 0.05$, ANOVA and Tukey post-test; panel $\mathrm{D}: \mathrm{P} \geqslant 0.05$, unpaired $t$-test.

\section{ATP-evoked currents were modulated by NO}

This set of experiments was performed to confirm whether the increase in the ATP-evoked current induced by $300 \mu \mathrm{M}$ L-arginine was due to an action of L-arginine 


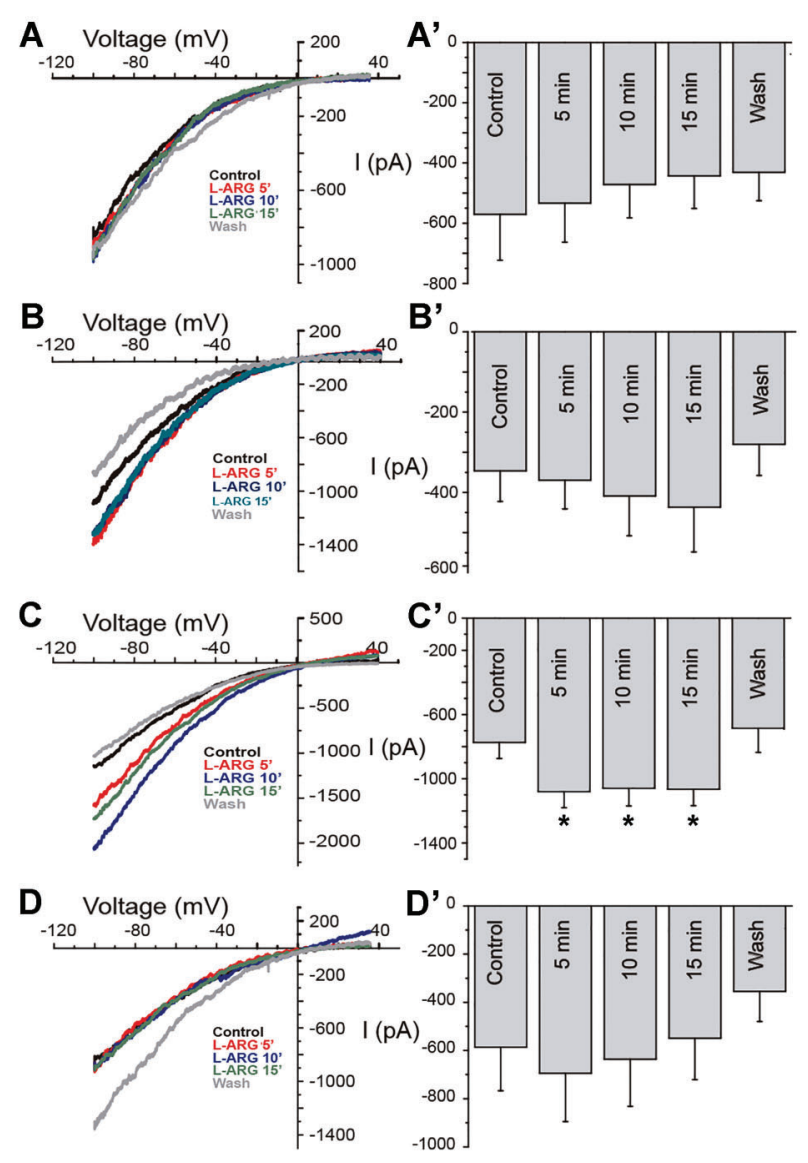

Figure 3. Effects of different concentrations of L-arginine on purinergic currents. $A, B, C$ and $D$, Representative $\mathrm{I} \times \mathrm{V}$ plots for the ATP-elicited currents after the treatment with $10 \mu \mathrm{M}(A), 100 \mu \mathrm{M}(B)$, $300 \mu \mathrm{M}(C)$, and $500 \mu \mathrm{M}(D)$ L-arginine for 5 (red), 10 (blue), and 15 min (green) followed by 15 min (gray) washing. $A^{\prime}$ ( $\mathrm{n}=9$ cells), $B^{\prime}$ ( $\mathrm{n}=8$ cells), $C^{\prime}\left(\mathrm{n}=7\right.$ cells), and $D^{\prime}$ ( $\mathrm{n}=8$ cells) show the means $\pm \mathrm{SE}$ of the current values at $-70 \mathrm{mV}$ for each group. Note the significant increase in the amplitude of the currents only with $300 \mu \mathrm{M}$ L-arginine. ${ }^{*} \mathrm{P} \leqslant 0.05, \mathrm{n}=7$ cells (ANOVA and Tukey post-test).

itself or to an increased NOS activity and consequently to NO. Figure 4 shows that 10 min incubation with $300 \mu \mathrm{M}$ L-arginine induced a significant increase in the ATP-evoked current. Nevertheless, a significant decrease was observed after 10 min superfusion of the cell with $300 \mu \mathrm{M} \mathrm{L}$-arginine associated with $1 \mathrm{mM}$ L-NAME (control: $-206.9 \pm 78.2$; L-arginine: $-308.3 \pm 98.6$; L-arginine + L-NAME: $-230.7 \pm$ $74.1 \mathrm{pA} ; . \mathrm{P} \leqslant 0.05, \mathrm{n}=7$ ), confirming that $\mathrm{NO}$ was directly responsible for modulating the purinergic currents

\section{NO modulated the ATP-induced current through a cGMP pathway}

It is widely known that $\mathrm{NO}$ can regulate $\mathrm{Ca}^{2+}$ homeostasis through a NO-cGMP-PKG pathway playing different roles in different tissues. To verify if the cGMP modulates purinergic currents in Leydig cells, we repeated

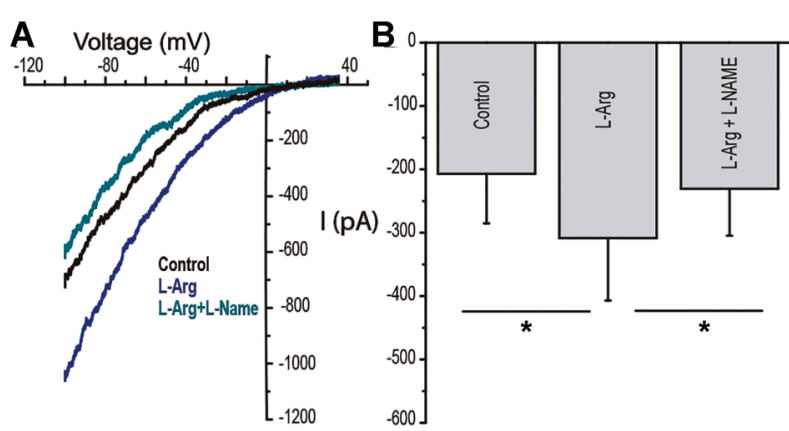

Figure 4. Three hundred $\mu \mathrm{M} \mathrm{L}$-arginine modulated purinergic currents. $A, \mathrm{I} \times \mathrm{V}$ relationship of ATP-evoked currents in control (black), after $10 \mathrm{~min}$ L-arginine incubation (blue), and after $10 \mathrm{~min}$ treatment with $300 \mu \mathrm{M} \mathrm{L-arginine}+1 \mathrm{mM}$ L-NAME (light green). The bar graph in $B$ shows the mean \pm SE amplitude of the ATP current at $-70 \mathrm{mV}$. ${ }^{*} \mathrm{P} \leqslant 0.05, \mathrm{n}=7$ cells (ANOVA and Tukey posttest).

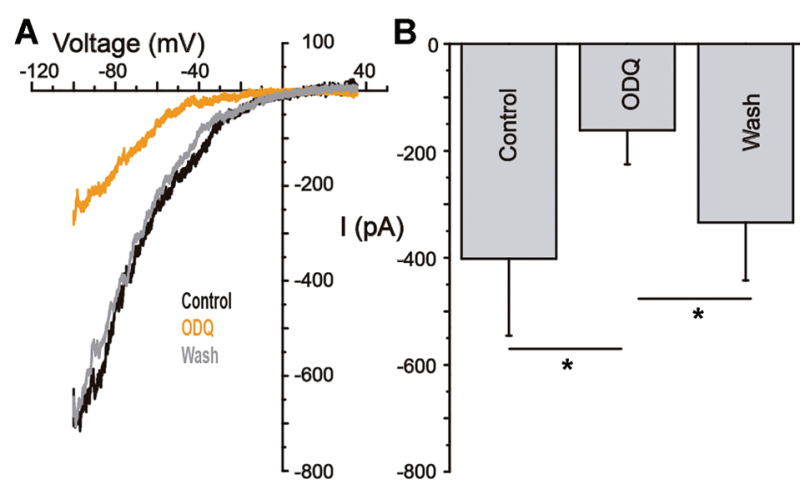

Figure 5. cGMP modulated purinergic currents. $A, I \times V$ relationship for ATP-evoked currents in control condition (black), after 10 min ODQ incubation (orange), and after washing with Hank's solution (gray). The bar graph in $B$ shows the mean \pm SE amplitude for the currents measured at $-70 \mathrm{mV}$. Note the significant amplitude decrease after $O D Q$ incubation and its recovery after washing with Hank's solution. ${ }^{*} \mathrm{P} \leqslant 0.05, \mathrm{n}=5$ cells (ANOVA and Tukey post-test).

the ATP stimulation protocol in the presence of $300 \mu \mathrm{M}$ $O D Q$, a selective guanylate cyclase inhibitor. Figure 5 shows ATP-evoked currents recorded before ODQ, after 10 min of incubation with ODQ and after washing out ODQ (Figure $5 \mathrm{~A}$ ) and the average current amplitudes measured at $-70 \mathrm{mV}$ (Figure $5 \mathrm{~B}$ ). ODQ caused a significant decrease in the ATP-evoked current amplitudes at $-70 \mathrm{mV}$, which were readily reversed upon ODQ washout (control: $-401.8 \pm 143.5 \mathrm{pA} ; 10 \mathrm{~min}$ ODQ incubation: $-161.6 \pm 63.6$ pA; washout: $-333.9 \pm 108.3 p A ; P \leqslant 0.05, n=6$ ).

To investigate whether the nitrergic modulation of purinergic current is dependent on the activation of the guanylate cyclase (GC) enzyme, we recorded ATP-induced currents in control conditions, 10 min after treatment with L-arginine, and 10 min after superfusion with L-arginine 
associated with ODQ (Figure 6A). As seen before, there was an increase in the ATP current upon treatment with L-arginine compared to control, and a clear decrease in the amplitude upon ODQ application (Figure 6B; control: $-334.7 \pm 131.3$; L-arginine: $-440.6 \pm 136.7$; L-arginine + ODQ: $-181 \pm 58.4 \mathrm{pA} ; \mathrm{P} \leqslant 0.05)$.

To confirm the involvement of cGMP in the modulation of the purinergic currents, we repeated the measurements after $10 \mathrm{~min}$ of treatment with $100 \mu \mathrm{M}$ 8-Br-cGMP, a membrane permeable cGMP analog, and after $10 \mathrm{~min}$ of treatment with 8-Br-cGMP associated with $300 \mu \mathrm{M}$ ODQ (Figure 7A). Figure 7 shows that 8-Br-cGMP enhanced the ATP currents per se (control: $-386.5 \pm 124.8 \mathrm{pA}$; 8-BrcGMP: $-541.5 \pm 137.1 \mathrm{pA}$ ). As expected, GC blockade by ODQ led to a significant decrease in the current amplitude even when the cells were treated with 8-Br-cGMP (-332.4 \pm 139.4 pA; $P \leqslant 0.05$; Figure 7B).

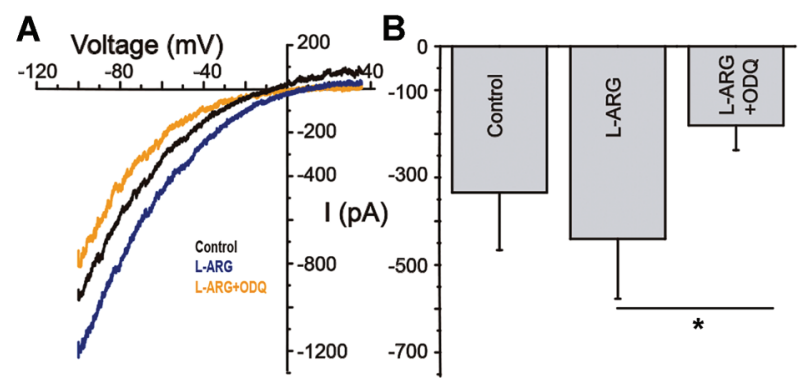

Figure 6. Purinergic modulation is dependent of the soluble guanylate cyclase (sGC). $A, \mathrm{I} \times \mathrm{V}$ plot of the ATP-evoked currents in control condition (black), after $10 \mathrm{~min}$ of incubation with L-arginine (blue), and after 10 min of treatment with L-arginine + $\mathrm{ODQ}$ (orange). The bar graph in $B$ shows the means $\pm \mathrm{SE}$ amplitude for the currents measured at $-70 \mathrm{mV}$. We observed a significant decrease in current amplitudes after sGC inhibition. ${ }^{*} \mathrm{P} \leqslant 0.05, \mathrm{n}=6$ cells (ANOVA and Tukey post-test).

\section{Discussion}

In this study, we demonstrated that purinergic and nitrergic systems interact in mice Leydig cells. Our results show that the purinergic current amplitudes were not directly modulated by NO produced in basal conditions but that activation of NOS with L-arginine modified the ATPinduced current. Interestingly, L-arginine had its strongest effect on the purinergic currents at a concentration of 300 $\mu \mathrm{M}$, since significant changes in the amplitude of currents at lower $(10$ e $100 \mu \mathrm{M})$ as well as higher concentrations $(500 \mu \mathrm{M})$ were not observed. The effect is mediated by GC, since ODQ blocks the effects of both L-arginine and of 8-bromo-cGMP. Even though the rate of desensitization of purinergic currents in Leydig cells is dependent on the concentration and exposure time to ATP (4), we overcame this issue with a specifically designed ATP application protocol. First ATP was applied for a short time (1400 ms) avoiding a major desensitization component. Second, we chose to apply a voltage ramp at the peak of the ATP effect, avoiding voltage pulses with long durations. Figure $1 \mathrm{~A}$ clearly shows that desensitization was not of significance under these conditions.

Treating the cells with L-NAME, a NOS inhibitor, revealed that basal $\mathrm{NO}$, at least in Leydig cells, was not enough to significantly modify the amplitude of the ATPinduced currents. This finding agrees with other results showing no significant effects of L-arginine when used in the lower range of concentrations (Figure $3 \mathrm{~A}$ ). This sort of effect is also seen in endothelial cells from blood vessels, where the plasma concentration of L-arginine $(100$ to $800 \mu \mathrm{M})$ is more than enough to support NO synthesis ( $\mathrm{nNOS} \mathrm{K}_{\mathrm{m}}$ : 1.4-2.2 $\mu \mathrm{M}$, inducible and endothelial NOS: 2.8-32.3 and $2.9 \mu \mathrm{M}$, respectively) (20). Nevertheless, further increases in the extracellular concentration of L-arginine raises $\mathrm{NO}$ synthesis even more. This phenomenon is described as the "arginine paradox": extra L-arginine is necessary for NO
A

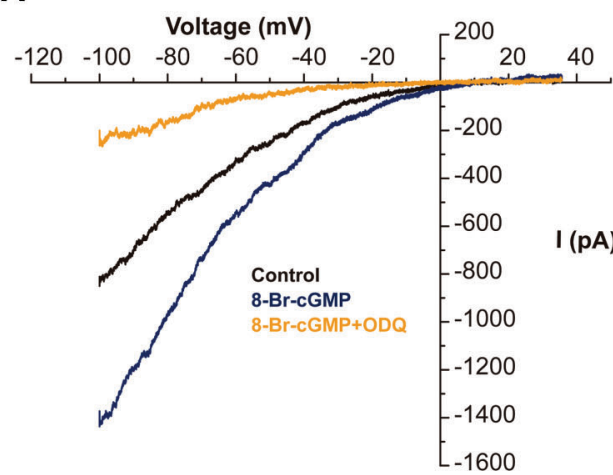

B

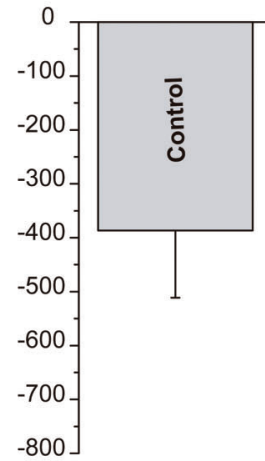

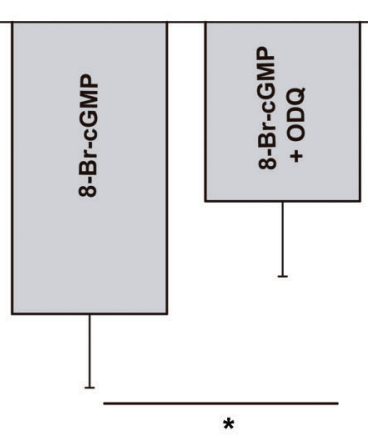

Figure 7. NO modulates purinergic current by the cGMP pathway. $A, I \times V$ plots for the ATP-evoked currents in control condition (black), after 10 min of treatment with 8-Br-cGMP (dark blue), and after 10 min incubation with 8-Br-cGMP + ODQ (orange). The bar graph in $B$ shows the mean \pm SE amplitude of the ATP current at $-70 \mathrm{mV}$. Note the significant amplitude decrease after the soluble guanylate cyclase ( $\left(\mathrm{GC}\right.$ ) enzyme inhibition. ${ }^{*} \mathrm{P} \leqslant 0.05, \mathrm{n}=6$ cells (ANOVA and Tukey post-test). 
synthesis even in the presence of intracellular saturating levels of the substrate (21).

Concerning the additional NO demand to induce modulation of the ATP-evoked current, we observed that $300 \mu \mathrm{M} \mathrm{L}$-arginine was able to change the currents during our observation time (i.e., $15 \mathrm{~min}$ ). Also, we can assure that the effect was due to the presence of the substrate, since the washing out of L-arginine brought the currents back to its initial values. A different response was observed for testosterone production, since low concentrations of NO donors (SNAP, DEA/NO, and DETA/NO) increase and high concentrations decrease hormone production (12).

The substrate modulatory effect on the ATP currents is reinforced by the significant reduction of their amplitude when the cells were incubated in the concomitant presence of L-NAME and L-arginine. In this aspect, studies related to the effects of $\mathrm{NO}$ on hormone production by Leydig cells are contradictory: Gaytán et al. (22) showed a reduction in testosterone production after a $1 \mathrm{~g} / \mathrm{kg} \mathrm{L-AME}$ (exogenous substrate of NOS) intraperitoneal injection; Weissman et al. (23), on the other hand, described no alteration of testosterone production in either the absence or presence of the substrate. We may argue that these antagonistic observations may be due to differences in experimental protocols (substrate concentration, cell condition, methodologies used).

Treatment of Leydig cells with ODQ reduced the amplitude of the ATP-evoked currents. After washout of the $\mathrm{GC}$ inhibitor, the currents returned to their original values. Also, treatment of the cells with $8 \mathrm{Br}-\mathrm{cGMP}$ confirmed the direct involvement of cGMP in modulating the ATP-induced currents (Figure 7). The effects of soluble guanylate cyclase (sGC) and cGMP were studied in human Leydig cells by Davidoff et al. (24). More recently, Andric et al. (25) identified, in vitro, the $\alpha 1$ and $\beta 1$ sGC subunits in Leydig cells. They also showed that these cells produce less testosterone and have smaller concentration

\section{References}

1. Janszen FH, Cooke BA, Van Driel MJ, Van Dar Molen HJ. The effect of calcium ions on testosterone production in Leydig cells from rat testis. Biochem J 1976; 160: 433-437, doi: 10.1042/bj1600433.

2. Pérez-Armendariz EM, Nadal A, Fuentes E, Spray DC. Adenosine $5^{\prime}$-triphosphate (ATP) receptors induce intracellular calcium changes in mouse leydig cells. Endocrine 1996; 4: 239-247, doi: 10.1007/BF02738690.

3. Foresta C, Rossato M, Nogara A, Gottardello F, Bordon P, Di Virgilio F. Role of P2-purinergic receptors in rat Leydig cell steroidogenesis. Biochem J 1996; 320: 499-504, doi: 10.1042/bj3200499.

4. Poletto Chaves LA, Pontelli EP, Varanda WA. P2X receptors in mouse Leydig cells. Am J Physiol Cell Physiol 2006; 290: 1009-107, doi: 10.1152/ajpcell.00506.2005.

5. Antonio LS, Costa RR, Gomes MD, Varanda WA. Mouse Leydig cells express multiple P2X receptor subunits. of cGMP when incubated with the sGC inhibitor NS2028 associated to the NO donor DPTA. Our data, showing a modulatory role of SGC and CGMP on the ATP-evoked currents in mice Leydig cells, are in accordance with the above results.

Our findings are also in accordance with a previous study by Shen et al. (26), demonstrating that $\mathrm{Ca}^{2+}$ homeostasis may be regulated by $\mathrm{NO}$ through a NO-cGMPPKG pathway. After treatment of the cells with L-arginine and $O D Q$, the currents were significantly diminished, unveiling the contributions of SGC and NO/cGMP signaling pathway to the modulatory effect exerted by NO. Del Punta et al. (10) showed that there is no increase in the cGMP production with or without GC after the incubation of Leydig cells with the NO donor DEA/NO. Matsunobu and Schacht (27) showed a decrease in intracellular $\left[\mathrm{Ca}^{2+}\right]$ when cochlear cells were treated with DEA/NO, SNP, and 8Br-cGMP, and an increase when GC was blocked by LY83583. However, Khurana et al. (28) showed that atrial natriuretic factor (ANF), cerebral natriuretic factor (CNF) and type $C$ natriuretic peptide (CNP) augmented the GC activity and cGMP in Leydig cells. They also observed that the cGMP inhibitor LY83583 diminished testosterone production. Taken together, our data and that of Khurana et al. (28) clearly show an involvement of sGC and GC, respectively, and the participation of cGMP in the process, reinforcing the role played by this second messenger in steroidogenesis directly and indirectly through the modulation of purinergic currents.

\section{Acknowledgments}

We thank Mr. José Fernando Aguiar for technical assistance. J.L. de Deus was supported by fellowships from CAPES and CNPQ and the laboratory of W.A. Varanda was supported by FAPESP (2012/19750-7).

Purinergic Signal 2009; 5: 277-287, doi: 10.1007/s11302008-9128-9.

6. Antonio LS, Stewart AP, Varanda WA, Edwardson JM. Identification of $\mathrm{P} 2 \mathrm{X} 2 / \mathrm{P} 2 \mathrm{X} 4 / \mathrm{P} 2 \mathrm{X} 6$ heterotrimeric receptors using atomic force microscopy (AFM) imaging. FEBS Lett 2014; 588: 2125-2128, doi: 10.1016/j.febslet.2014.04.048.

7. Rettori V, Belova N, Dees WL, Nyberg CL, Gimeno M, Mccann SM. Role of nitric oxide in the control of luteinizing hormone-releasing hormone release in vivo and in vitro. Proc Natl Acad Sci USA 1993; 90: 10130-10134, doi: 10.1073/ pnas.90.21.10130.

8. Adams ML, Nock B, Truong R, Cicero TJ. Nitric oxide control of steroidogenesis: endocrine effects of NG-nitro-L-arginine and comparisons to alcohol. Life Sci 1992; 50: 35-40, doi: 10.1016/0024-3205(92)90384-2.

9. Welch C, Watson ME, Poth M, Hong T, Francis GL. Evidence to suggest nitric oxide is an interstitial regulator 
of Leydig cell steroidogenesis. Metabolism 1995; 44: $234-$ 238, doi: 10.1016/0026-0495(95)90271-6.

10. Del Punta K, Charreau EH, Pignataro OP. Nitric oxide inhibits Leydig cell steroidogenesis. Endocrinology 1996; 137: 53375343, doi: 10.1210/endo.137.12.8940355.

11. Nee Pathak ND, Lal B. Nitric oxide: An autocrine regulator of Leydig cell steroidogenesis in the Asian catfish, Clarias batrachus. Gen Comp Endocrinol 2008; 158: 161-167, doi: 10.1016/j.ygcen.2008.06.009.

12. Valenti S, Cuttica CM, Fazuolli L, Giordano G, Giusti M. Biphasic effect of nitric oxide on testosterone and cyclic gmp production by purified rat leydig cells cultured in vitro. Int $J$ Androl 1999; 22: 336-341, doi: 10.1046/j.1365-2605.1999.00189.x.

13. Alderton WK, Cooper CE, Knowles RG. Nitric oxide synthases: structure, function and inhibition. Biochem $J$ 2001; 357: 593-615, doi: 10.1042/bj3570593.

14. Zini A, O’Bryan MK, Magid MS, Schlegel PN. Immunohistochemical localization of endothelial nitric oxide synthase in human testis, epididymis, and vas deferens suggests a possible role for nitric oxide in spermatogenesis, sperm maturation, and programmed cell death. Biol Reprod 1996; 55: 935-941, doi: 10.1095/biolreprod55.5.935.

15. Kim HC, Byun JS, Le TK, Jeong CW, Ahn M, Shin T. Expression of nitric oxide synthase isoforms in the testes of pigs. Anat Histol Embryol 2007; 36: 135-138, doi: 10.1111/ j.1439-0264.2006.00739.x

16. Shen J, Harada N, Yamashita T. Nitric oxide inhibits adenosine 5'-triphosphate-induced $\mathrm{Ca}^{2+}$ response in inner hair cells of the guinea pig cochlea. Neurosci Lett 2003; 337: 135-138, doi: 10.1016/S0304-3940(02)01320-4.

17. Yao ST, Gourine AV, Spyer KM, Barden JA, Lawrence AJ. Localisation of $\mathrm{P} 2 \mathrm{X} 2$ receptor subunit immunoreactivity on nitric oxide synthase expressing neurones in the brain stem and hypothalamus of the rat: a fluorescence immunohistochemical study. Neuroscience 2003; 121: 411-419, doi: 10.1016/ S0306-4522(03)00435-4.

18. Silva G, Baierwaltes WH, Garvin JL. Extracellular ATP stimulates NO production in rat thick ascending limb. Hypertension 2006; 47: 563-567, doi: 10.1161/01.HYP.0000197 954.93874.ef.

19. Lowe M, Park SJ, Nurse CA, Campanucci VA. Purinergic stimulation of carotid body efferent glossopharyngeal neurones increases intracellular $\mathrm{Ca}^{2+}$ and nitric oxide production.Exp Physiol 2013; 98: 1199-1212, doi: 10.1113/expphysiol.2013. 072058.

20. Förstermann $U$, Schmidt HH, Pollock JS, Sheng H, Mitchell JA, Warner TD, et al. Isoforms of nitric oxide synthase. Characterization and purification from different cell types. Biochem Pharmacol 1991; 42: 1849-1857, doi: 10.1016/ 0006-2952(91)90581-O.

21. Kurz S, Harrison DG. Insulin and the arginine paradox. J Clin Invest 1997; 99: 369-370, doi: 10.1172/JCl119166.

22. Gaytán F, Bellido C, Aguilar R, Morales C, Van Rooijen N, Aguilar E. Role of the testis in the response of the pituitarytesticular axis to nitric oxide-related agents. Eur J Endocrinol 1997; 137: 301-308, doi: 10.1530/eje.0.1370301.

23. Weissman B, Niu E, Ge R, Sottas CM, Holmes M, Hutson $\mathrm{JC}$, et al. Paracrine modulation of androgen synthesis in rat leydig cells by nitric oxide. J Androl 2005; 26: 369-378, doi: 10.2164/jandrol.04178.

24. Davidoff MS, Middendorff R, Mayer B, De Vente J, Koesling $D$, Holstein AF. Nitric oxide/cGMP pathway components in the Leydig cells of the human testis. Cell Tissue Res 1997; 287: 161-170, doi: 10.1007/s004410050742.

25. Andric SA, Janjic MM, Stojkov NJ, Kostic TS. Protein kinase G-mediated stimulation of basal Leydig cell steroidogenesis. Am J Physiol Endocrinol Metab 2007; 293: 1399-1408, doi: 10.1152/ajpendo.00482.2007.

26. Shen J, Harada N, Nakazawa H, Yamashita T. Involvement of the nitric oxide-cyclic GMP pathway and neuronal nitric oxide synthase in ATP-induced $\mathrm{Ca}^{2+}$ signalling in cochlear inner hair cells. Eur J Neurosci 2005; 21: 2912-2922, doi: 10.1111/j.1460-9568.2005.04135.x.

27. Matsunobu T, Schacht J. Nitric oxide/cyclic GMP pathway attenuates ATP-evoked intracellular calcium increase in supporting cells of the guinea pig cochlea. J Comp Neurol 2000; 423: 452-461, doi: 10.1002/1096-9861(20000731)423:3< 452::AID-CNE8 > 3.0.CO;2-Y.

28. Khurana ML, Pandey KN. Receptor-mediated stimulatory effect of atrial natriuretic factor, brain natriuretic peptide, and C-type natriuretic peptide on testosterone production in purified mouse Leydig cells: activation of cholesterol side-chain cleavage enzyme. Endocrinology 1993; 133: 2141-2149, doi: 10.1210/endo.133.5.8404664. 